\title{
SOCIALIZATION OF ECO-FRIENDLY PACKAGING AGRICULTURAL PRODUCTS INCREASING VALUE ADDED PRODUCTS IN NORTH KEMBANGAN VILLAGE, WEST JAKARTA
}

\author{
${ }^{1 *}$ Fransisca LISTYANINGSIH, ${ }^{2}$ Nurul HIDAYAH, ${ }^{3}$ Putri Renalita Sutra TANJUNG, \\ and ${ }^{4}$ Dian Primanita OKTASARI \\ Accounting Major, Faculty Economics and Business, Universitas Mercu Buana, Jakarta \\ *fransisca.listyaningsih@mercubuana.ac.id; nurul.hidayah@mercubuana.ac.id; putri.renalita@mercubuana.ac.id; \\ dian.primanita@mercubuana.ac.id
}

\begin{abstract}
The rise of organic food production lately encourages consumers to be aware of the safety and health of the products they consume. Organic agricultural products are vegetables and fruit produced from agriculture that are environmentally friendly, more natural and sustainable so that they are in great demand so that the price of these vegetable soars. These organic vegetable and fruit products are easily damaged by environmental factors and the nature of the product. The choice of packaging will determine how safe the product is and how the packaging can attract the attention of consumers. The most commonly used packaging for agricultural products such as organic vegetables and fruit is made of plastic. Currently, plastic is the largest contributor to waste that pollutes the environment. The use of environmentally friendly materials as a substitute for plastic packaging is very potential because generally these environmentally friendly materials are used as packaging for food products but have not been used for agricultural products, such as organic vegetables and fruits. Leaves and bamboo can also be used for packaging vegetable and fruit products. The use of leaves for packaging vegetable and fruit products can maintain the color, freshness, aroma and texture of vegetables and fruit.
\end{abstract}

Keywords: Organic Products, Eco-Friendly Packaging, Product Value-Added.

\section{BACKGROUND}

Marketing in the current era of globalization is the most important factor for a profit or non-profit company or organization. Environmental changes that occur continuously in the development process of a country either directly or indirectly affect the life of the economic system, marketing methods and human behavior. Several studies have proven that food produced from natural processing has a higher level of safety than food products produced using chemicals. The large number of organic food production today encourages consumers to be aware of the safety and health of the products they consume.

One of the disadvantages of organic products is the relatively short shelf life. According to Musdalifah (2012), the nature of organic products that cannot be stored for long is one of the factors that influence the distribution process so that the alternative that can be done is storage.

Improved storage capability and durability of organic products during distribution as well as display in marketing (market display), depending on the packaging application. Proper packaging can reduce the rate of transpiration and postharvest respiration rate of organic products. Packaging is an activity to protect the freshness of organic products, especially organic agriculture during transportation, distribution and or storage so that product quality is maintained. The function of packaging is to protect the commodity from physical, mechanical and microbiological damage, create attractiveness for consumers and provide added value to the product and extend the shelf life of the product (Sembiring, 2009).

The most common packaging for organic agricultural products is using plastic. According to Sembiring (2009), packaging of agricultural products is usually done by packing in sacks to facilitate the transportation process, using cardboard or plastic for low-temperature storage.
Plastic packaging has several advantages, including low prices, easy to apply, able to reduce the rate of transpiration and postharvest respiration of agricultural products, light weight, transparent so that the packaged material looks visible from the outside, and is easy to obtain. Plastic packaging also has a major drawback which is not environmentally friendly. Plastic packaging and materials made from other plastics are the biggest contributors to waste that pollutes the environment, because plastic is a material that is difficult to decompose in nature.

Environmental pollution due to plastic waste can be reduced by using eco- friendly materials, including the use of eco-friendly packaging. Eco-friendly packaging has begun to be widely produced, but its distribution is still very limited. Agricultural product packaging that is often found in the market is still made of plastic and it is still rare to use eco-friendly packaging, whether it has been processed such as biodegradable packaging or simple packaging made from natural materials such as leaves or bamboo. Leaves are often only used as packaging for agricultural products in traditional markets and not as packaging.

The potential of leaves and bamboo as a substitute for plastic packaging is quite high, because leaves and bamboo have been used as food wrappers in the community. Leaves and bamboo can also be used for packaging organic vegetable and fruit products. Use of leaves for packaging of vegetable and fruit products.

\section{Focus on Community Service}

The district 07 area, North Kembangan Village, West Jakarta is a densely populated residential area. Settlements in this area have narrow yards but residents continue to cultivate crops using a hydroponic system (urban farming) which does not require large land and does not require a 
lot of water so it is very easy and suitable to be applied in urban areas that have limited land.

Urban farming in the district 07 area is well developed. Every citizen makes the farmland at home more productive by growing various vegetables. The harvested vegetables are organic vegetables that do not contain pesticides and are marketed to supermarkets.

The packaging used for these organic vegetables is plastic. One of the dangers of plastic is that it cannot be decomposed, causing pollution. Therefore, it is necessary to have eco-friendly materials that can be used for packaging organic agricultural products while maintaining the color, freshness, aroma and texture of organic agricultural products.

\section{Justification And Targets}

Marketing in the era of globalization is the spearhead for a company, both profit and non-profit organizations. Environmental changes that occur continuously in the development process of a country affect the life of the economy, marketing methods and human behavior, both directly and indirectly. Several studies have proven that food produced from natural processing has a higher level of safety than food products produced using chemicals. The development of organic food production encourages consumers to be aware of the safety and health of the products they consume.

Organic vegetables are vegetables produced from agriculture that are eco-friendly and refer to back to nature concept and many people like it. Both in terms of production and marketing, these organic vegetables are easily damaged by environmental factors and the nature of the product itself. Therefore, proper post-harvest handling is required. One important aspect is packaging which is one of the product attributes. This packaging will distinguish non-organic vegetables from organic vegetables.

The most commonly used packaging for organic agricultural products is the use of plastic. Plastic packaging has several advantages, including low prices, easy to apply, able to withstand the rate of transpiration and postharvest respiration of agricultural products, light weight, transparent so that the packaged material looks visible from the outside, and is easy to obtain. Plastic packaging also has a major danger which not eco-friendly. Plastic packaging and materials made from other plastics are the largest contributor to waste that pollutes the environment, this is because plastic is a material that is difficult to decompose in nature.

\section{Identification of Problems}

From the identification of these problems, several important points were obtained, residents of Kelurahan Kembangan Utara, West Jakarta do not yet know the types of eco-friendly packaging for organic agricultural products and have not used packaging made of ecofriendly materials, such as leaves and bamboo for organic agricultural products to increase sales and product valueadded.

\section{Relevance}

This community service is expected to contribute to the purchase intention of eco-friendly products so as to increase sales and product value-added.

\section{METHOD}

The method of implementing the activities is divided into four stages. The initial stage is the pre-activity stage. This stage is carried out by visiting the training location and discussing the technical implementation of activities with the leadership of the North Kembangan Village, the head of District 07 and the head of the family welfare organization, preparing materials, tools and training materials and setting targets who will become training participants. After the pre-activity stage, the next stage is directing. At this directing stage, training participants are given an overview of the nature of organic agricultural products, the advantages and disadvantages of plastic packaging and types of eco-friendly packaging. The next stage is the implementation of the training. This stage provides education to training participants regarding the introduction of eco-friendly packaging that is suitable for the physical, mechanical and microbiological properties of organic agricultural products and the use of packaging as a marketing tool to increase sales and product value-added.

The last stage in this activity is the post-test. At this stage, participants were given a questionnaire regarding training materials on eco-friendly packaging suitable for organic agricultural products, the results of the training program as well as feedback from training participants that helped in improving the training.

\section{RESULTS AND DISCUSSION}

\section{Results}

\begin{tabular}{|c|c|c|}
\hline No & Output Type & $\begin{array}{c}\text { Performance } \\
\text { Indicator }\end{array}$ \\
\hline 1 & $\begin{array}{l}\text { Scientific publications in ISSN jurnals/ } \\
\text { proceeding 1) }\end{array}$ & Draft \\
\hline 2 & Publication in print/online/repository media 6) & Reached \\
\hline 3 & $\begin{array}{l}\text { Increasing competitiveness (increasing } \\
\text { quality, quantity, and value added of goods, } \\
\text { services, product diversification, or other } \\
\text { resources 4) }\end{array}$ & Reached \\
\hline 4 & $\begin{array}{l}\text { Improvement of science and technology } \\
\text { in society (mechanization, IT, and } \\
\text { management) 4) }\end{array}$ & - \\
\hline 5 & $\begin{array}{l}\text { Improvement of community values } \\
\text { (cultural, social, political, security, security, } \\
\text { education, health) 2) }\end{array}$ & Reached \\
\hline 6 & Publication in international journal 1) & Reached \\
\hline 7 & $\begin{array}{l}\text { Services, social engineering, methods or } \\
\text { systems, products / goods } 5 \text { ) }\end{array}$ & Reached \\
\hline 8 & New Innovation atau TTG 5) & - \\
\hline 9 & $\begin{array}{l}\text { Intellectual property rights (Patents, simple } \\
\text { patents, copyrights, trademarks, trade } \\
\text { secrets, industrial product design, protection } \\
\text { of plant varieties, protection of integrated } \\
\text { circuit toography designs) 3) }\end{array}$ & - \\
\hline 10 & Book with ISBN 6) & - \\
\hline
\end{tabular}




\section{Discussion}

The stages carried out by the community service team before the counseling were surveys and interviews with residents in District 07, Kembangan Utara Village, West Jakarta. The next stage is to make an agreement with the residents through the district administrators and family welfare organization administrators.

The next stage is to make an agreement with residents and family welfare organization members through the district management and family welfare organization administrators. After there is an agreement with the residents and the district and family welfare organization, the next step is to make invitations for the training participants, all residents and family welfare organization members in district 07 Kembangan Utara Village, West Jakarta. This community activity is an eco-friendly packaging suitable for organic agricultural products, made of bamboo and leaves, which is carried out online through google meet.

The eco-friendly packaging education for organic agricultural products was opened by the Head of district 07 by giving a speech about urban farming activities that have been carried out by residents of district 07 but still use traditional plastic packaging. The opening of this activity was also attended by the lecturer implementing the activity. After the opening ceremony, continued with an explanation of the nature of organic agricultural products, advantages and disadvantages of plastic packaging and types of eco-friendly packaging, types of eco-friendly packaging that is suitable for the physical, mechanical and microbiological properties of organic agricultural products and the use of packaging as a marketing tool to increase sales and product value-added.

\section{CONCLUSIONS AND RECOMMENDATION}

In accordance with technological developments and lifestyles, traditional packaging for organic agricultural products is no longer used by the community because it is considered unhygienic and impractical. Then slowly replaced with man-made wrappers/containers that we now usually use such as plastic and styrofoam. So far, modern containers and wrappers give a modern, practical and clean impression. But the problem is, this material is difficult to recycle, causing waste in layers, thus polluting the environment. With the emergence of various environmental pollution problems, a solution is needed to maintain and create traditional packaging that is more suitable for use, namely traditional packaging that still uses natural ingredients but is still attractive. Traditional packaging must appear unique and have the strength to maintain the color, texture and taste of organic products.

Eco-friendly packaging uses natural materials so that the color, taste and texture of organic products can be maintained and extend shelf life. The flexibility and uniqueness of the packaging appearance is intended to have attractiveness and aesthetic value while remaining focused on the physical, mechanical and microbiological properties of the product so as to increase the added value of the product and sales. In addition, this ecofriendly packaging can be recycled so it does not cause environmental pollution.

\section{REFERENCE}

Hendra, A.H. \& Andoko, A. 2014. Bertanam Sayuran Hidroponik Ala Pak Tani The Farmer Hydrofarm. PT Agromedia Pustaka

Herudiyanto, Marleen S. 2008. Teknologi Pengemasan Pangan. Bandung: Widya Padjadjaran.

I Nyoman, S., Ketut S., Pande K. D. K. 2017. Pengemasan Pangan: Kajjian Pengemasan yang Aman, Nyaman, Efektif, dan Efisien. Udayana University Press. Bali.

Musdalifah, N. 2012. Perubahan Warna Pada Cabai Rawit (Capsicum frutescense) Selama Pengeringan Lapisan Tipis. Skripsi. Universitas Hasanuddin. Makassar.

Mourad, Mahadan Yasser Ahmed. 2012. Perception of Green Brand in an Emerging Innovative Market. Emeraldinsight, 15:4.

Roidah, I. S. 2015. Pemanfaatan Lahan dengan Menggunakan Sistem Hidroponik. Jurnal Bonorowo 1(2): 43-49.

Sembiring, N. N. 2009. Pengaruh jenis bahan pengemas terhadap kualitas produk cabai merah (Capsicum annuum, L.) segar kemasan selama penyimpanan dingin [tesis]. Medan: Sekolah Pascasarjana, Universitas Sumatera Utara. 